\title{
Inhibition of Helicobacter pylori infection by bovine milk glycoconjugates in a BALB/cA mouse model
}

\author{
X. WANG, S. HIRMO, R. WILLÉN* and T. WADSTRÖM \\ Department of Infectious Diseases and Medical Microbiology, University of Lund, Lund and * Department of \\ Pathology, Sahlgrenska University Hospital, Gothenburg, Sweden
}

\begin{abstract}
The attachment of Helicobacter pylori to the human gastric mucosa is a complex process involving several specific structures recognised by the cell surface receptors. Sialylated multivalent high mol. wt glycoproteins have been shown to inhibit $H$. pylori sialic acidspecific haemagglutination. This study explored whether sialylated glycoconjugates from bovine milk could inhibit an experimental $H$. pylori infection in a mouse model. BALB/cA mice (6-8 weeks old) were inoculated with a mouse-passaged $H$. pylori strain 317p. Four weeks after infection the mice were given lactoferrin (iron-free LF or $20 \%$ iron-saturated LF) or bovine milk fat globule membrane fractions (MFGM or defatted MFGM) orally $(400 \mathrm{mg} / \mathrm{kg}$ body weight) once daily for 10 days and then killed to examine for bacterial colonisation and gastritis. Mice treated with iron-free LF, 20\% iron-saturated LF, MFGM or defatted MFGM showed 30\%, 10\%, 20\% or $20 \%$ healing rates, respectively, when compared with the $H$. pylori-infected control. Gastric colonisation by $\boldsymbol{H}$. pylori was remarkably decreased in all mice treated with bovine milk glycoconjugates and the inflammation score was also significantly lower in treated mice than in infected control animals. The fact that there was no significant difference between iron-free LF and iron-saturated LF or MFGM and defatted MFGM suggested that iron is not crucial for inhibition of $H$. pylori by lactoferrin and that the lipid part of MFGM is not important for anti- $H$. pylori activity. In conclusion, bovine milk glycoconjugates showed potencies to inhibit $H$. pylori infection in this mouse model and, therefore, could be considered as candidates for non-antibiotic strategies against $H$. pylori infection in man.
\end{abstract}

\section{Introduction}

Helicobacter pylori is the causative agent of chronic type B gastritis and a key factor in peptic ulcer disease, stomach cancer and MALT lymphoma [1-3]. The attachment of $H$. pylori to the human gastric mucosa is a complex process involving several specific structures recognised by gastric mucin and cell surface receptors [4]. H. pylori sialic acid-binding haemagglutinin(s) represent a group of such putative cell surface adhesins, proposed to be crucial for the bacterial colonisation of the stomach [5]. Sialylated glycoconjugates in gastrointestinal mucins, as well as sialylated bovine milk glycoproteins, inhibit $H$. pylori sialic acidspecific haemagglutination [6]. Lactoferrin (LF) is an iron-binding glycoprotein that is found in various

Received 31 May 2000; revised version accepted 23 Oct. 2000.

Corresponding author: Professor T. Wadström (e-mail: torkel.wadstrom@mmb.lu.se). secretions, including tears, milk, and semen, and also in the secretory granules of neutrophils. It has been reported to have various biological functions [7] and antibiotic properties against various gram-negative bacteria [8]. The components of bovine milk fat globule membrane are high mol. wt mucin and the roles of mucin-like components from milk in the prevention of bacterial adhesion have been reported for several pathogens [9-11].

The rapid increase of antibiotic resistance of various pathogenic microbes and the development of new resistance mechanisms are threats for the treatment of several infective diseases [12]. Of the potential novel non-antibiotic treatment strategies, anti-adhesive compounds to inhibit tissue invasion by bacterial pathogens are promising candidates $[13,14]$. This group of investigators has previously standardised a mouse model for $H$. pylori infection [15-17] and recently reported that antioxidants such as astaxanthin and vitamin $\mathrm{C}$ inhibit $H$. pylori infection in this model 
[18]. The present study investigated whether bovine milk glycoproteins could inhibit an experimental $H$. pylori infection in a $\mathrm{BALB} / \mathrm{cA}$ mouse model, to develop a possible anti-adhesion strategy in the future.

\section{Materials and methods}

\section{Glycoconjugates}

Milk fat globule membrane fractions (MFGM and defatted MGFM) were prepared from bovine buttermilk obtained from a butter-making plant of Snow Brand Milk Products (Tokyo, Japan) as described previously [6]. Lactoferrin (iron-free LF and 20\% iron-saturated LF) from bovine milk were also obtained from Snow Brand Milk Products. These milk compounds were dissolved in sterilised water just before administration.

\section{Bacterial strains}

A H. pylori mouse-passaged strain EU317p (originally isolated from a patient with gastritis), which is a $\mathrm{CagA}^{-}, \mathrm{VacA}^{-}$and sialic acid-binding strain, was used in this study. H. pylori was cultured on GAB-Camp agar (Gc agar base; Becton Dickinson, Franklin Lakes, USA) supplemented with horse serum $10 \%$ and incubated for $48 \mathrm{~h}$ at $37^{\circ} \mathrm{C}$ under micro-aerobic conditions [19]. The cells were harvested into $0.01 \mathrm{M}$ sodium phosphate buffer, $\mathrm{pH} 7.2$, containing $0.15 \mathrm{M}$ $\mathrm{NaCl}$ (PBS), centrifuged at $3000 \mathrm{rpm}$ for $10 \mathrm{~min}$ and resuspended in the same buffer to a final concentration of $10^{9} \mathrm{cfu} / \mathrm{ml}$.

\section{Animals}

Sixty conventional BALB/cA mice (6-8 weeks old) were used in this study (B\&K Universal Company, Stockholm, Sweden). Mice were housed with a 12-h light-dark schedule, fed with rat and mouse standard diet no. 2 (B\&K Universal Company) and allowed water ad libitum [15]. The experiment was done with the permission of a Swedish animal ethical committee in Lund.

\section{Experimental design}

Fifty mice were inoculated orally through a feeding tube three times at 2-day intervals with $0.1 \mathrm{ml}$ of a $H$. pylori suspension containing $10^{9} \mathrm{cfu} / \mathrm{ml}$, and as a negative control group, 10 mice, were given PBS only [17]. Inoculated mice were then randomly divided into five groups. Four groups of mice were given iron-free LF, 20\% iron-saturated LF, MFGM or defatted MFGM at a dose of $400 \mathrm{mg} / \mathrm{kg}$ body weight orally once daily for 10 days at 4 weeks after inoculation. Infected control and normal control mice were given distilled water through the feeding tube. Mice were killed after the final treatment and their stomachs were collected. Half of each stomach, including all types of mucosa, was fixed in $10 \%$ buffered formalin for histology studies [16]. The remaining part of the stomach was used to culture $H$. pylori.

\section{Culture}

Stomach biopsies were rinsed in phosphate-buffered saline (PBS), smeared directly on GAB-Camp agar and incubated at $37^{\circ} \mathrm{C}$ for $5-10$ days under micro-aerobic conditions [17]. The presence of $H$. pylori on the culture plates was confirmed by urease, catalase and oxidase tests, Gram's staining and PCR [15]. The absence of $H$. pylori colonies on the plate was classed as culture negative. The number of colonies per plate was counted as cfu/culture unit.

\section{Histopathology}

Murine stomach tissues were fixed in $10 \%$ buffered formalin, embedded in paraffin, then $4-\mu \mathrm{m}$ sections were prepared and stained with haematoxylin and eosin by standard procedures. The degree of inflammation was scored in a blind manner on a scale of $0-3$ for body and antrum as follows: 0, normal; 1, few inflammatory cells; 2, moderate inflammatory cells in several layers; 3 , high level of inflammation with nests containing $>50$ inflammatory cells, often in more than three cell layers [17]. The inflammation score of each mouse was calculated as the average of body and antrum.

\section{Growth inhibition assay}

Bacteria $\left(2 \times 10^{6} \mathrm{cfu}\right)$ were grown in triplicate tubes containing $2 \mathrm{ml}$ of trypticase soy broth (TSB) supplemented with horse serum $10 \%$ and Dent-supplement (Oxoid) with or without iron-free LF or $20 \%$ ironsaturated $\mathrm{LF}$ at $0.5-4 \mathrm{mg} / \mathrm{ml}$ at $37^{\circ} \mathrm{C}$. Samples $(20 \mu \mathrm{l})$ were taken 2 and 5 days after the start of incubation for counting viable cells. After incubation for 5 days, the bacterial cells were harvested by centrifugation and replaced with fresh medium without lactoferrin for a further 5 days growth. Turbidity was then measured at an optical density (OD) of $600 \mathrm{~nm}$. The control growth was set as $100 \%$ and inhibition of growth was given a value between 0 and $100 \%$.

\section{Haemagglutination inhibition assay}

Bacterial suspensions were diluted with PBS to give 4 haemagglutinating units (HAU) [6]. One HAU was defined as the amount of bacteria that caused complete agglutination. Inhibition tests were performed in the wells of U-shaped microtitration plates by mixing $15 \mu \mathrm{l}$ of bacterial sample with $15 \mu$ of a serial dilution of inhibitor for $1 \mathrm{~h}$ at room temperature, after which $15 \mu \mathrm{l}$ of human erythrocyte $0.75 \%$ suspension was added to each well and allowed to settle for $1-2 \mathrm{~h}$. 


\section{Adherence assay}

The adherence assay was done by the method described previously [20, 21]. Briefly, bacteria were pre-incubated with serially diluted inhibitors in wells of U-shaped microtitration plates for $15 \mathrm{~min}$ at room temperature. Then $25 \mu \mathrm{l}$ of the mixture from each well was added to HeLa S3 cell monolayers (derived from a cervix carcinoma) and incubated with gentle agitation for $20 \mathrm{~min}$ at room temperature. Monolayers were washed three times with $100 \mu \mathrm{l}$ of PBS to remove unbound bacteria. Remaining bacteria were quantified by the urea-phenol red assay. The inhibitory concentration (IC) was calculated as a percentage from the following formula: Inhibition $(\%)=\left[\left(\mathrm{OD}_{\text {experimental }}-\mathrm{OD}_{\text {negative }}\right) /\left(\mathrm{OD}_{\text {positive }}\right.\right.$ $\left.\left.-\mathrm{OD}_{\text {negative }}\right)\right] \times 100$, where negative wells contained only epithelial monolayers without bacteria and positive wells contained bacteria and monolayer without inhibitor.

\section{Statistical analysis}

The Mann-Whitney $U$ test and $\chi^{2}$ test were used for defining colonisation and inflammation distribution. The level of significance was selected as $\mathrm{p}<0.05$.

\section{Results}

All 10 mice in the infected control group were $H$. pylori culture positive at 5.5 weeks after inoculation. In the groups treated with iron-free LF or $20 \%$ ironsaturated LF, seven or nine mice within each group of 10 mice were $H$. pylori culture positive. Of the mice treated with MFGM or defatted MFGM, eight of 10 animals were $H$. pylori culture positive (Table 1). There was no statistical difference between any of the treated groups of mice and infected control animals. However, only $30 \%, 10 \%, 20 \%$ and $20 \%$ healing rates, respectively, were obtained from $H$. pylori-infected mice after treatment with iron-free LF, $20 \%$ ironsaturated LF, MFGM and defatted MFGM.

The numbers of $H$. pylori colonies cultured from gastric biopsies were significantly decreased in mice treated with iron-free LF or $20 \%$ iron-saturated LF compared with $H$. pylori-infected control animals

Table 1. H. pylori culture from mouse gastric biopsies

\begin{tabular}{lcr}
\hline Groups of mice & $\begin{array}{c}\text { H. pylori- } \\
\text { positive/ } \\
\text { total mice }\end{array}$ & $\begin{array}{c}\text { Healing } \\
\text { rate } \\
(\%)\end{array}$ \\
\hline Normal & $0 / 10$ & 100 \\
H. pylori & $10 / 10^{*}$ & 0 \\
H. pylori + lactoferrin (iron-free) & $7 / 10$ & 30 \\
H. pylori + lactoferrin $(20 \%$ & $9 / 10$ & 10 \\
$\quad$ iron-saturated) & & \\
H. pylori + MFGM & $8 / 10$ & 20 \\
H. pylori + defatted MFGM & $8 / 10$ & 20 \\
\hline
\end{tabular}

${ }^{*} \mathrm{p}<0.01$ versus normal mice by $\chi^{2}$ test. There was no statistical difference between any treated group and the infected control group.
( $\mathrm{p}<0.01)$. MFGM or defatted MFGM also decreased H. pylori colonisation in the mouse stomachs remarkably when compared with the $H$. pylori-infected control animals $(\mathrm{p}<0.05)$ (Fig. 1). There was no significant difference between the bovine milk glycoconjugates tested in this model.

The infected control mice showed severe inflammation in the stomach when compared with normal control mice 5.5 weeks after inoculation $(\mathrm{p}<0.001)$. The LF (iron-free or $20 \%$ iron-saturated)- and MFGM (fat or defatted) -treated mice showed a significant decrease in inflammation score compared with infected control animals $(\mathrm{p}<0.05)$ (Fig. 2), but still had a significantly higher inflammation score than non- $H$. pylori-inoculated animals $(\mathrm{p}<0.001)$. The histopathological analysis of these different groups of mice is illustrated in Fig. 3.

The effect of bovine lactoferrin on the growth of $H$. pylori strain 317 was examined in vitro in broth culture. The mean IC50 was $1 \mathrm{mg} / \mathrm{ml}$ for iron-free LF and $4 \mathrm{mg} / \mathrm{ml}$ for iron-saturated LF (Table 2). Incubation for 5 days with various concentrations of LF showed a greater inhibitory effect on growth of $H$. pylori than incubation for 2 days (data not shown). Both bovine MFGM and its defatted fraction inhibited haemagglutination of $H$. pylori at similar concentrations (Table 2). Iron-saturated LF inhibited haemagglutination of $H$. pylori, whereas iron-free LF did not inhibit haemagglutination at a concentration of $33 \mathrm{mg} / \mathrm{ml}$ (Table 2). The cell adherence assay demonstrated that all the milk glycoconjugates tested inhibited the binding of $H$. pylori to HeLa S3 cell monolayers (Table 2).

\section{Discussion}

This study aimed to investigate whether sialylated glycoconjugates from bovine milk could inhibit an experimental $H$. pylori infection in BALB/cA mice. It was found that all tested bovine milk glycoproteins decreased the gastric colonisation of $H$. pylori and the gastritis.

Iron-free and iron-saturated LF showed 30\% and 10\% healing rates of $H$. pylori colonisation in this mouse model. Lactoferrin can act as an antimicrobial agent like transferrin through iron deprivation or can damage the outer membrane of bacteria directly by the binding of lactoferrin [22,23]. Recently, the iron uptake of various Helicobacter species was compared [24]. It was found that gastric Helicobacter spp., except $H$. pylori, were non-siderophore-producing organisms and were able to obtain iron only from haem and haemoglobin. However, non-gastric Helicobacter spp. produced siderophores and were able to use a wide range of iron sources for growth, such as bovine and human lactoferrin and transferrin, haem and haemo- 


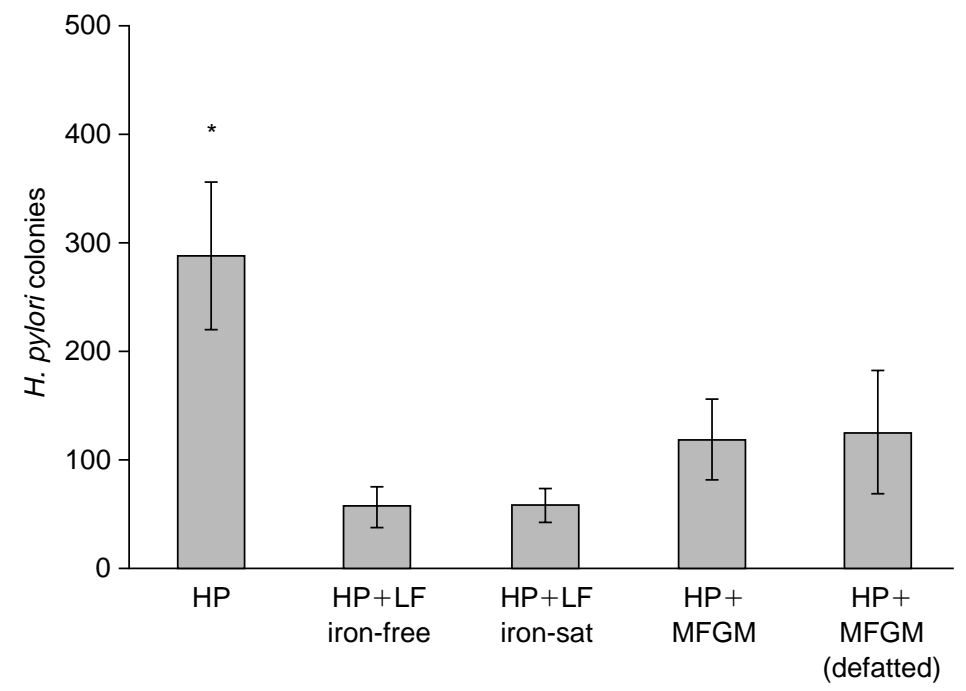

Fig. 1. Inhibition of $H$. pylori colonisation in mice by bovine milk glycoconjugates. All treated mice showed significantly lower gastric colonisation than the infected control mice $\left({ }^{*} p<0.01\right.$ versus LF and $p<0.05$ versus MFGM). Data are mean values with SEM.

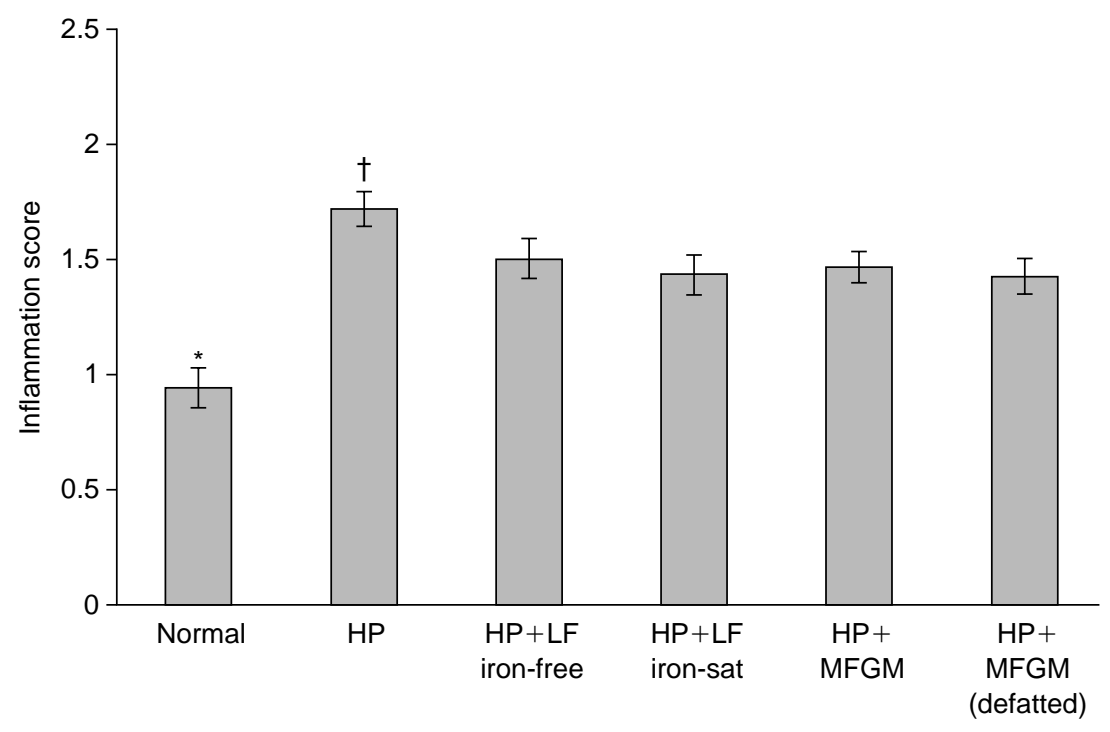

Fig. 2. Inflammation score of gastritis in BALB/cA mice treated with milk compounds. ${ }^{*} \mathrm{p}<0.001$ versus all H. pyloriinfected mice; $\uparrow \mathrm{p}<0.05$ versus all treated groups. Data are mean values with SEM.

globin. Antibiotic-like properties of bovine lactoferrin against $H$. pylori growth through iron deprivation have been reported and the treatment of $H$. felis-infected mice with lactoferrin partially reversed mucosal disease manifestations [25]. In the experimental $H$. pylori mouse model used in the present study, lactoferrin inhibition of $H$. pylori infection was independent of iron-scavenging properties, as both iron-free and 20\% iron-saturated LF gave similar effects in vivo and in the adhesion assay. In a germ-free mouse model, bovine lactoferrin (30\% iron-saturated) decreased the number of $H$. pylori colonies significantly and inhibited the attachment of $H$. pylori to the stomach mucosa [26]. Iron-free LF inhibited $H$. pylori growth in vitro at a lower concentration $(1 \mathrm{mg} / \mathrm{ml})$ compared with ironsaturated LF $(4 \mathrm{mg} / \mathrm{ml})$. The involvement of the ingested lactoferrin in the stimulation of carbohydrate absorption, which is independent of its iron-chelating capacity as in vitro, has been proposed as the mechanism of bovine lactoferrin-induced bacteriostasis in vivo [27].

Sialylated bovine milk glycoproteins inhibit $H$. pylori sialic acid-specific haemagglutination effectively [6]. In the mouse model studied, both MFGM and defatted MFGM decreased gastric H. pylori colonisation and its associated gastritis. The lipid part of the MFGM fraction does not seem to be involved in this mechanism, as similar results were obtained with a delipidated preparation in both in-vivo and in-vitro experiments. The importance of sialylated oligosaccharides on human gastric epithelial cells as binding 

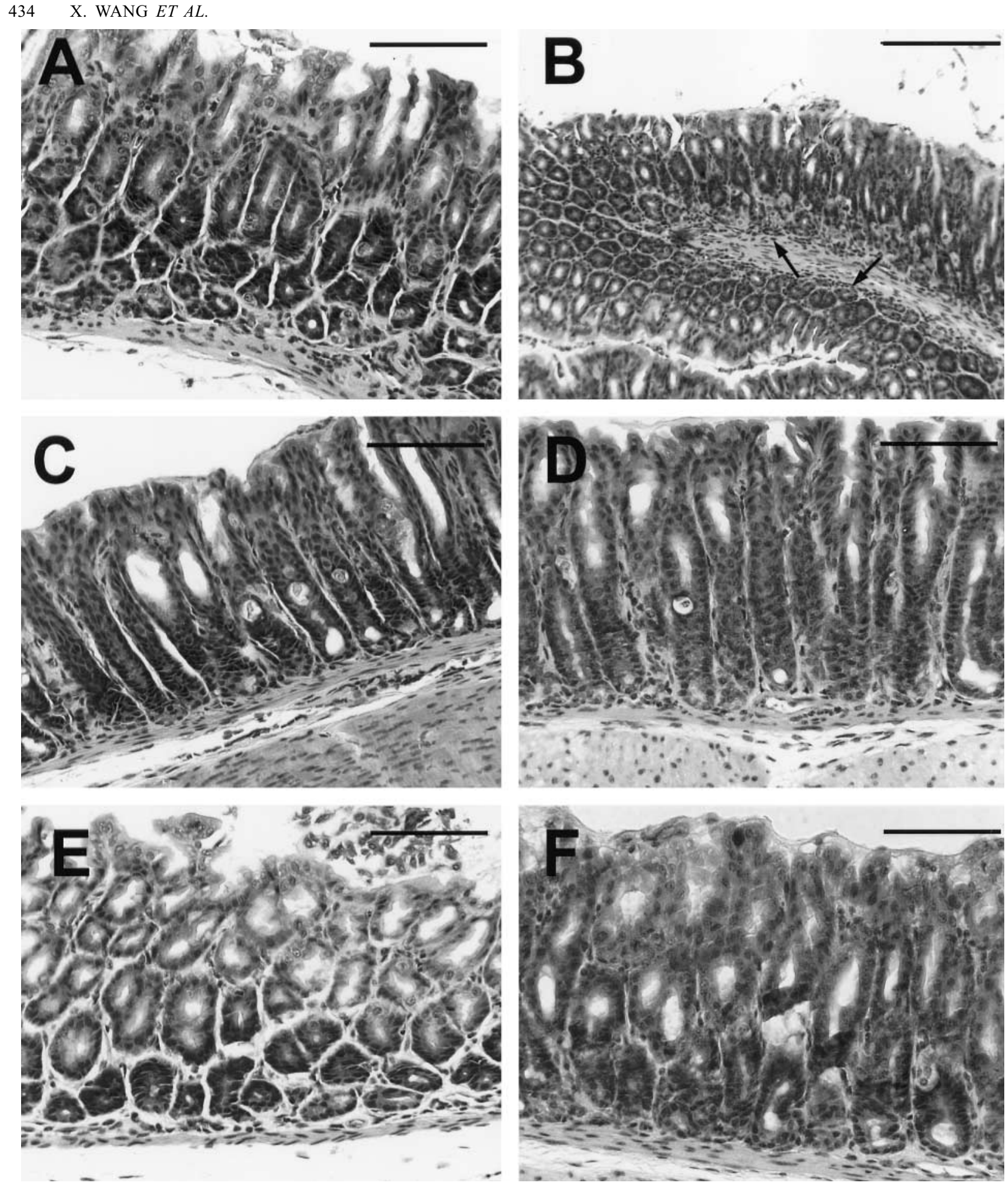

Fig. 3. Histopathological analysis of mouse stomachs. (A) Normal control animal: only a few lymphocytes, inflammation score 0.5 ; (B) $H$. pylori-infected control animal: heavy infiltrate of granulocytes, lymphocytes and plasma cells close to muscular mucosa (arrows) and also many inflammation cells between crypts, inflammation score 2.5; (C, D) H. pylori-infected mice treated with iron-free LF or iron-saturated LF: only a few cells around the lamina muscularis mucosa and scattered inflammatory cells in-between glands, inflammation scores 1 and 1.5, respectively; (E, F) $H$. pylori-infected mice treated with MFGM or defatted MFGM: very few cells around the lamina muscularis mucosa and scattered inflammatory cells in-between glands, score 1 . Magnification $\times 20($ bar $=100 \mu \mathrm{m})$.

sites for $H$. pylori has been described [21] and 3'sialyllactose (3'SL) suppressed H. pylori infection in a rhesus monkey model [13]. Monkeys treated with 3'SL at $100 \mathrm{mg}$ or $500 \mathrm{mg} / \mathrm{kg}$ body weight/day for 28 and 56 days showed a $33 \%$ curing rate (two of six animals). The dose of MFGM used to treat the infected mice in the present study was $400 \mathrm{mg} / \mathrm{kg}$ body weight/day, which is similar to that used in the monkeys. Prolonging the therapeutic period may increase the healing rate for $H$. pylori infection.

A Mongolian gerbil model was recently optimised to study the gastric inflammation response to $H$. pylori infection with a strong induction of pro- and anti- 
Table 2. Inhibition of $H$. pylori growth, haemagglutination and binding to HeLa S3 monolayers

\begin{tabular}{lccc}
\hline & \multicolumn{3}{c}{ Concentration that caused $50 \%$ inhibition of $(\mathrm{IC} 50 \mathrm{mg} / \mathrm{ml})$} \\
\cline { 2 - 4 } Inhibitor & growth & haemagglutination & adhesion \\
\hline Lactoferrin (iron-free) & 1 & $>33$ & 2.81 \\
Lactoferrin (20\% iron-saturated) & 4 & 0.2 & 2.5 \\
MFGM & $\mathrm{NT}$ & 0.065 & 5.63 \\
Defatted MFGM & $\mathrm{NT}$ & 0.031 & 5.31 \\
\hline
\end{tabular}

NT, not tested.

oxidants [28]. Also, a guinea-pig model has been developed for experimental $H$. pylori infection yielding a strong gastric inflammation response [29]. These animal models may now be used to evaluate various candidates for a non-antibiotic treatment strategy to combat $H$. pylori infections.

In conclusion, inhibition of $H$. pylori infection in this mouse model with selected milk glycoconjugates looks promising. However, longer duration of therapy or a combination of several glycoconjugates could possibly yield better results. The anti-adhesion concept should be investigated further for possible use in $H$. pylori infections in man.

This study was supported by grants from the Swedish Medical Research Council (16X04723), Swedish Council for Agricultural Research, Medical Faculty of Lund University, Kungliga Fysiografiska Sällskapet in Lund (Sweden) and Snow Brand Milk Products (Tokyo, Japan).

\section{References}

1. Cover TL, Blaser MJ. Helicobacter pylori and gastroduodenal disease. Annu Rev Med 1992; 43: 135-145.

2. Ernst P. Review article: the role of inflammation in the pathogenesis of gastric cancer. Aliment Pharmacol Ther 1999; 13 Suppl 1: 13-18.

3. Morgner A, Bayerdorffer E, Neubauer A, Stolte M. Gastric MALT lymphoma and its relationship to Helicobacter pylori infection: management and pathogenesis of the disease. Microsc Res Tech 2000; 48: 349-356.

4. Wadström T, Hirmo S, Borén T. Biochemical aspects of Helicobacter pylori colonization of the human gastric mucosa. Aliment Pharmacol Ther 1996; 10 Suppl 1: 17-27.

5. Logan RPH. Adherence of Helicobacter pylori. Aliment Pharmacol Ther 1996; 10 Suppl 1: 3-15.

6. Hirmo S, Kelm S, Iwersen M et al. Inhibition of Helicobacter pylori sialic acid-specific haemagglutination by human gastrointestinal mucins and milk glycoproteins. FEMS Immunol Med Microbiol 1998; 20: 275-281.

7. Lönnerdal B, Iyer S. Lactoferrin: molecular structure and biological function. Annu Rev Nutr 1995; 15: 93-110.

8. Levay PF, Viljoen M. Lactoferrin: a general review. Haematologica 1995; 80: 252-267.

9. Kanamaru Y, Etoh M, Song XG et al. A high-Mr glycoprotein fraction from cow's milk potent in inhibiting replication of human rotavirus in vitro. Biosci Biotechnol Biochem 1999; 63: $246-249$.

10. Schroten H, Hanisch FG, Plogmann $\mathrm{R}$ et al. Inhibition of adhesion of S-fimbriated Escherichia coli to buccal epithelial cells by human milk fat globule membrane components: a novel aspect of the protective function of mucins in the nonimmunoglobulin fraction. Infect Immun 1992; 60: 28932899.

11. Peterson JA, Patton S, Hamosh M. Glycoproteins of the human milk fat globule in the protection of the breast-fed infant against infections. Biol Neonate 1998; 74: 143-162.

12. Goddard AF. Getting to the route of Helicobacter pylori treatment. J Antimicrob Chemother 1998; 42: 1-3.

13. Mysore JV, Wigginton T, Simon PM, Zopf D, Heman-Ackah LM, Dubois A. Treatment of Helicobacter pylori infection in rhesus monkeys using a novel antiadhesion compound. Gastroenterology 1999; 117: 1316-1325.

14. Breithaupt $H$. The new antibiotics. Can novel antibacterial treatments combat the rising tide of drug-resistant infections? Nat Biotechnol 1999; 17: 1165-1169.

15. Wang X, Sjunnesson $H$, Sturegård E, Wadström T, Willén R, Aleljung P. Dietary factors influence the recovery rates of Helicobacter pylori in a BALB/cA mouse model. Zentralbl Bakteriol 1998; 288: 195-205.

16. Wang X, Sturegård E, Rupar R et al. Infection of BALB/c A mice by spiral and coccoid forms of Helicobacter pylori. $J$ Med Microbiol 1997; 46: 657-663.

17. Wang X, Willén R, Wadström T, Aleljung P. RAPD-PCR. Histopathological and serological analysis of four mouse strains infected with multiple strains of Helicobacter pylori. Microbial Ecology in Health and Disease 1998; 10: 148-154.

18. Wang X, Willén R, Wadström T. Astaxanthin-rich algal meal and vitamin $\mathrm{C}$ inhibit Helicobacter pylori infection in BALB/cA mice. Antimicrob Agents Chemother 2000; 44: 2452-2457.

19. Soltez V, Schalén C, Mårdh PA. New selective medium for Campylobacter pylori. In: Kaijser B, Falsen E (eds) Proceedings of the Fourth International Workshop on Campylobacter infections. University of Gothenburg, Gothenburg, Sweden, 1988: 433-436.

20. Wadström T, Hirmo S, Novak $\mathrm{H}$ et al. Sulfatides inhibit binding of Helicobacter pylori to the gastric cancer Kato III cell line. Curr Microbiol 1997; 34: 267-272.

21. Simon PM, Goode PL, Mobasseri A, Zopf D. Inhibition of Helicobacter pylori binding to gastrointestinal epithelial cells by sialic acid-containing oligosaccharides. Infect Immun 1997; 65: $750-757$.

22. Teraguchi S, Shin K, Ozawa K et al. Bacteriostatic effect of orally administered bovine lactoferrin on proliferation of Clostridium species in the gut of mice fed bovine milk. Appl Environ Microbiol 1995; 61: 501-506.

23. Ellison RT. The effects of lactoferrin on gram-negative bacteria. Adv Exp Med Biol 1994; 357: 71-90.

24. Dhaenens L, Szczebara F, Van Nieuwenhuyse S, Husson MO. Comparison of iron uptake in different Helicobacter species. Res Microbiol 1999; 150: 475-481.

25. Dial EJ, Hall LR, Serna H, Romero JJ, Fox JG, Lichtenberger LM. Antibiotic properties of bovine lactoferrin on Helicobacter pylori. Dig Dis Sci 1998; 43: 2750-2756.

26. Wada T, Aiba Y, Shimizu K, Takagi A, Miwa T, Koga Y. The therapeutic effect of bovine lactoferrin in the host infected with Helicobacter pylori. Scand J Gastroenterol 1999; 34: 238-243.

27. Ogata T, Teraguchi S, Shin K et al. The mechanism of in vivo bacteriostasis of bovine lactoferrin. Adv Exp Med Biol 1998; 443: $239-246$

28. Suzuki H, Mori M, Seto K et al. Helicobacter pyloriassociated gastric pro- and antioxidant formation in Mongolian gerbils. Free Radic Biol Med 1999; 26: 679-684.

29. Sturegård E, Sjunnesson H, Ho B et al. Severe gastritis in guinea-pigs infected with Helicobacter pylori. J Med Microbiol 1998; 47: 1123-1129. 